\title{
THE USE OF HYPERBARIC OXYGENATION IN POSTOPERATIVE TREATMENT OF OBLITERATING ARTERIAL DISEASE OF THE LOWER EXTREMITIES UNDERGOING VASCULAR RECONSTRUCTIVE SURGERY
}

\section{ZASTOSOWANIE TLENOTERAPII HIPERBARYCZNEJ W POOPERACYJNYM LECZENIU CHOROBY ZAROSTOWYCH TĘTNIC KOŃCZYN DOLNYCH PO OPERACJI REKONSTRUKCJI NACZYNIOWEJ}

\author{
Oleksandr Oliynyk $\mathbf{k}^{1(\mathrm{~A}, \mathrm{~B}, \mathrm{C}, \mathrm{D}, \mathrm{E}, \mathrm{F})}$
}

${ }^{1}$ Pope John Paul II State School of Higher Education in Biała Podlaska, Poland

Authors' contribution Wkład autorów: A. Study design/planning zaplanowanie badań B. Data collection/entry zebranie danych C. Data analysis/statistics dane - analiza i statystyki D. Data interpretation interpretacja danych E. Preparation of manuscript przygotowanie artykułu F. Literature analysis/search wyszukiwanie $\mathrm{i}$ analiza literatury G. Funds collection zebranie funduszy
Tables: 1

Figures: 2

References: 11

Submitted: 2020 March 26

Accepted: 2020 May 18

\section{Summary}

Background. Hyperbaric oxygenation is successfully used in the treatment of many diseases accompanied by hypoxia. The purpose of this work was to study the oxygen balance in patients with obliterating arterial disease of the lower extremities who received hyperbaric oxygen along with usual therapy following reconstructive vascular surgery.

Material and methods. 18 patients with obliterating arterial disease of the lower extremities were studied. Measurements were taken using gasometry and tetrapolar rheography. On the basis of arterial blood oximetry data and cardiac output indicators, determined reographically, volumetric indexes of delivery and consumption of the oxygen by the body and the volume of intrapulmonary bypass of blood were calculated.

Results. Inclusion of hyperbaric oxygenation as five 45-minute sessions at a pressure of 1.5 atm in the postoperative intensive care of patients with obliterating arterial disease of the lower extremities, undergoing reconstructive vascular surgery, was found to lead to significant improvements in the oxygen balance of the body, increasing the oxygen transport capacity of the blood, increasing the physiological reserve of organs and systems of the body and aligning of the metabolic processes of the tissues.

Conclusions. Hyperbaric oxygenation can be successfully used in the postoperative treatment of patients with obliterating arterial diseases of the lower extremities undergoing vascular reconstructive surgery.

Keywords: lower extremities, hyperbaric oxygenation, arteries, obliterating diseases

\section{Streszczenie}

Wprowadzenie. Tlenoterapia hiperbaryczna jest skuteczną terapią wielu chorób, którym towarzyszy hipoksja. Celem niniejszej pracy jest zbadanie bilansu tlenowego u pacjentów z chorobami zarostowymi tętnic kończyn dolnych, którzy oprócz standardowej terapii po operacji rekonstrukcji naczyniowej zostali poddani tlenoterapii hiperbarycznej.

Materiał i metody. Przebadano 18 pacjentów z chorobami zarostowymi tętnic dolnych za pomocą gazometrii i reografii tetrapolarnej. Na podstawie danych oksymetrycznych i frakcji wyrzutowej serca określonej reograficznie obliczono wskaźniki objętości tlenu zarówno dostarczanego, jak i zużywanego przez ciało oraz objętość śródpłucnego przecieku krwi.

Wyniki. Włączenie tlenoterapii hiperbarycznej $w$ formie pięciu czterdziestopięciominutowych sesji z ciśnieniem o wartości 1,5 atmosfery do pooperacyjnej intensywnej terapii pacjentów z chorobami zarostowymi kończyn dolnych, którzy zostali poddani operacjom rekonstrukcyjnym tętnic, prowadzi do znacznej poprawy bilansu tlenowego ciała, zwiększenia objętości transportu tlenu we krwi, zwiększenia fizjologicznej rezerwy organów i układów oraz koniunkcji procesów metabolicznych tkanek.

Wnioski. Tlenoterapia hiperbaryczna może być skutecznie stosowana w terapii pooperacyjnej pacjentów z chorobami zarostowych tętnic kończyn dolnych po operacji rekonstrukcji naczyniowej.

Słowa kluczowe: kończyny dolne, tlenoterapia hiperbaryczna, tętnice, choroby zarostowe 


\section{Introduction}

Patients with obliterating arterial diseases of the lower extremities have regional and often general oxygen balance disorders. Therefore, after vascular reconstructive surgery, it is reasonable to include sessions of hyperbaric oxygenation (HBO) into the generally accepted principles of postoperative therapy to aid in the correction of tissue hypoxia (by stabilizing perfusion pressure, improving microcirculation, optimizing blood rheological properties, normalizing metabolic processes of tissues, etc.). It is important to study the oxygen balance in such patients, since the obtained results will make it possible to optimize hyperbaric oxygenation modes to obtain maximum therapeutic effect $[1,2]$.

The purpose of this work is to study the state of oxygen exchange in patients with obliterating arterial diseases of the lower extremities, undergoing vascular reconstructive surgery, 24 hours after five sessions of hyperbaric oxygenation.

\section{Material and methods}

18 male patients with obliterating arterial disease of the lower extremity, undergoing vascular reconstructive surgery, aged 53 to 72 years, with a mean age of $62.4+/-6.3$, were studied. Patients had smoked for an average of 41.6 years and had concomitant chronic obstructive pulmonary disease (COPD) stage II in remission. The control group comprised 15 healthy men between the ages of 50 and 70 with mean age $63.2+/-5.5$ years. 12 patients of this group smoked for an average of 23.1 years.

All patients had chronic limb ischemia Fontaine stage IV or Rutherford III degree/category 5. All patients had previously underwent femoral-popliteal shunting. Hyperbaric oxygenation was started on average $14.2+/-3.2$ days after surgery. In the postoperative period, along with usual postoperative care, patients were prescribed HBO as five 45 minute sessions in a day at a pressure of 1.5 atm [1]. Patients were evaluated with gasometry [3-5] and tetrapolar rheography [6] 24 hours after surgery, and 24 hours after the last session of HBO. Using arterial blood oximetry data and cardiac output indicators determined reographically; volumetric indexes of delivery $\left(\mathrm{DO}_{2}\right)$ and consumption $\left(\mathrm{VO}_{2}\right)$ of the oxygen by the body and the volume of intrapulmonary bypass of blood (B) were calculated [7].

The actual oxygen consumption, as well as its delivery, is measured in $\mathrm{ml} / \mathrm{min}$ and is calculated as the difference between the arterial and venous transport of $\mathrm{O}_{2}$ :

$$
\begin{gathered}
\mathrm{VO}_{2}=\left[\text { arterial delivery of } \mathrm{O}_{2}-\text { venous return of } \mathrm{O}_{2}\right] \\
\mathrm{VO}_{2}=\mathrm{CO} \times\left(\mathrm{CaO}_{2}-\mathrm{CvO}_{2}\right)-\mathrm{CO} \times \mathrm{Hb} \times 1.34 \times\left(\mathrm{SaO}_{2}-\mathrm{SvO}_{2}\right) / 100
\end{gathered}
$$

where $\mathrm{VO}_{2}$ - is oxygen consumption (ml/min); $\mathrm{CO}$ - cardiac output (l/min); $\mathrm{CaO}_{2}$ and $\mathrm{CvO}_{2}-\mathrm{O}_{2}$ content, respectively, in arterial and mixed venous blood (ml/l); Hb - hemoglobin concentration (g/l); 1.34 - Hufner's constant (can vary from 1.34 to 1.39); $\mathrm{SaO}_{2}$ and $\mathrm{SvO}_{2}$ - saturation of $\mathrm{O}_{2}$ of arterial and mixed venous blood (\%); 100 is the unit conversion index.

The delivery of $\mathrm{O}_{2}$ to tissues can be calculated using the following equation:

$$
\mathrm{DO}_{2}=1.34 \times \mathrm{SaO}_{2} \times \mathrm{CO} \times \mathrm{Hb} / 100
$$

where $\mathrm{DO}_{2}$ - is a delivery of oxygen with arterial blood (ml/min); 1.34 - Hufner's constant; Hb - hemoglobin concentration in the blood (g/l); $\mathrm{SaO}_{2}$ - saturation of hemoglobin of arterial blood with oxygen (\%); $\mathrm{CO}$ - cardiac output (l/min); 100 is the conversion index.

In addition, the study used the methods used by Hnativ to assess the oxygen balance, which makes it possible to evaluate various components of the hypoxic process, in particular hypoxic, hemic and circulatory hypoxia. A comprehensive assessment of the above components of various types of hypoxia, according to the described methodology, makes it possible to calculate the integral indicator of oxygen deficiency (IIOD). The techniques described by Hnativ were used to an estimate of oxygen homeostasis [8]. In doing so, the IIOD, DPH - the degree of pulmonary hypoxia, DHH - the degree of hemic hypoxia and DCH - the degree of circulating hypoxia were calculated. 
All patients pre-signed an informed consent form to participate in the studies. Before the study, the work planning materials were submitted and approved by the Bioethics Commission of the Ternopil National Medical University, Ukraine, protocol No. 5 of March 4, 2019.

The data set was checked for distribution using the Shapiro-Fork test. As the original data had a normal distribution, Student's t-test was used to determine statistical significance of the averages. Statistical significance was regarded as significant at values of $\mathrm{p}<0.001$. Microsoft Excel 2010 and Statsoft STATISTICA 10 were used for calculations [9].

\section{Results}

We calculated oxygen balance indices in the preoperative period, however, these indices did not significantly differ from those in the early postoperative period. Therefore, we do not present the values of these preoperative indices. We observed a significant difference between some oxygen metabolism indices in the studied patients compared with healthy individuals (Table 1).

Table 1. Indices of oxygen homeostasis in patients with obliterating arterial disease of the lower extremities undergoing reconstructive vascular surgery 24 hours following surgery, and after five sessions of hyperbaric oxygenation (mean \pm standard deviation)

\begin{tabular}{|c|c|c|c|}
\hline \multirow[t]{2}{*}{ Parameter } & \multirow[t]{2}{*}{ Control group } & \multicolumn{2}{|c|}{$\begin{array}{c}\text { In patients with obliterating diseases of the arteries of } \\
\text { the lower extremities }\end{array}$} \\
\hline & & 24 hours following surgery & after 5 sessions of $\mathrm{HBO}$ \\
\hline $\mathrm{SaO}_{2}, \%$ & $96.0 \pm 1.0$ & $93.6 \pm 1.0$ & $94.8 \pm 0.5$ \\
\hline $\mathrm{paO}_{2}, \mathbf{m m ~ H g}$ & $86.5 \pm 5.6$ & $82.6 \pm 3.0$ & $83.8 \pm 3.1$ \\
\hline Shunt, l/min & $0.11 \pm 0.01$ & $0.28 \pm 0.02^{*}$ & $0.18 \pm 0.02$ \\
\hline $\begin{array}{l}\text { The degree of pulmonary } \\
\text { hypoxia, } \%\end{array}$ & $0.10 \pm 0.05$ & $2.40 \pm 0.21^{*}$ & $1.62 \pm 0.16$ \\
\hline The degree of hemic hypoxia, \% & $0.12 \pm 0.10$ & $7.11 \pm 0.22^{*}$ & $4.16 \pm 0.12^{* *}$ \\
\hline $\begin{array}{l}\text { The degree of circulatory } \\
\text { hypoxia, \% }\end{array}$ & $0.02 \pm 0.05$ & $5.08 \pm 0.17^{*}$ & $-0.51 \pm 0.05^{* *}$ \\
\hline $\begin{array}{c}\text { Integral indicator of oxygen } \\
\text { deficiency, } \%\end{array}$ & $0.22 \pm 0.05$ & $14.50 \pm 0.15^{*}$ & $5.21 \pm 0.22^{* *}$ \\
\hline $\mathrm{DO}_{2}, \mathrm{ml} / \mathrm{min}$ & $620.0 \pm 14.3$ & $530.6 \pm 21.4^{*}$ & $615.1 \pm 24.5^{* *}$ \\
\hline $\mathrm{VO}_{2}, \mathrm{ml} / \mathrm{min}$ & $140.5 \pm 9.6$ & $172.1 \pm 8.3^{*}$ & $164.2 \pm 11.1^{* *}$ \\
\hline Shunt, \% & $22.7 \pm 4.5$ & $32.4 \pm 2.2^{*}$ & $26.7 \pm 1.8^{* *}$ \\
\hline
\end{tabular}

Note: ${ }^{*}$ - the results are significant $(\mathrm{p}<0.01)$ for healthy individuals; ${ }^{* *}-$ the results are reliable $(\mathrm{p}<0.01)$ relative to the initial data.

In particular, a decreased arterial blood saturation, caused by blood bypass syndrome (B), a result of chronic obstructive pulmonary disease, was revealed in patients before the HBO sessions.

The degree of pulmonary hypoxia in the patients before treatment ranged from 0.1 to $2.4 \%$, the degree of hemic hypoxia from 0.12 to $7.4 \%$, and circulatory from 0.02 to $5.08 \%$. The value of oxygen delivery in the examined patients before treatment was less than that in healthy patients by $17 \%$ (Figure 1, Figure 2). 


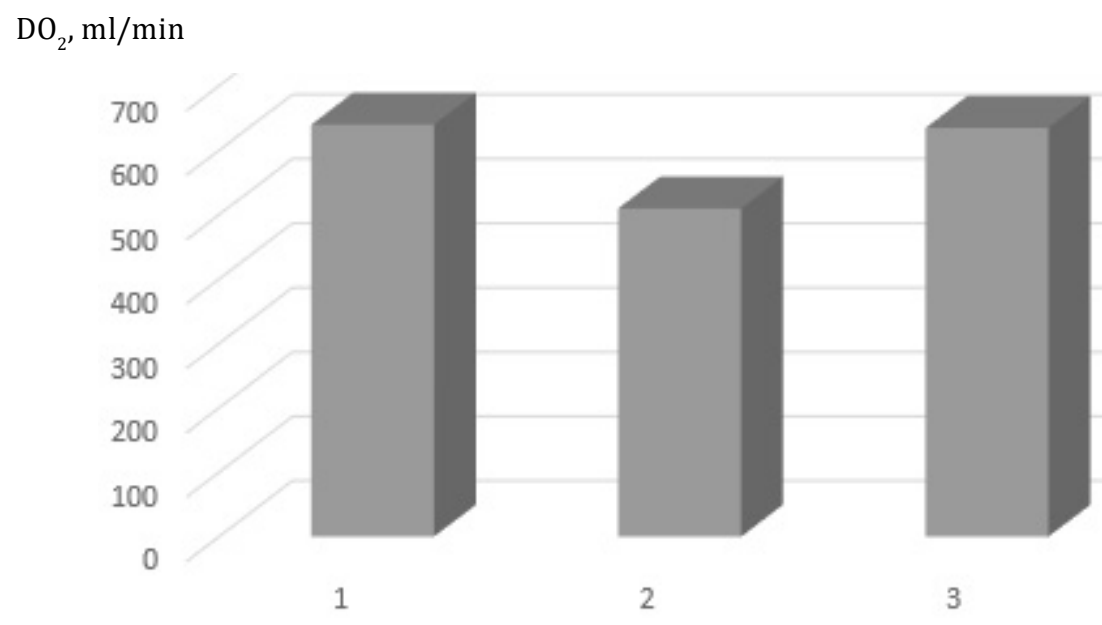

1. Healthy individuals

2. Patients with obliterating diseases of the arteries of the lower extremities a day after surgery

3. Patients with obliterating diseases of the arteries of the lower extremities after 5 sessions of HBO

Figure 1. The effect of hyperbaric oxygenation on oxygen delivery in patients with chronic obliterating disease of the arteries of the lower extremities

Oxygen deficiency, \%

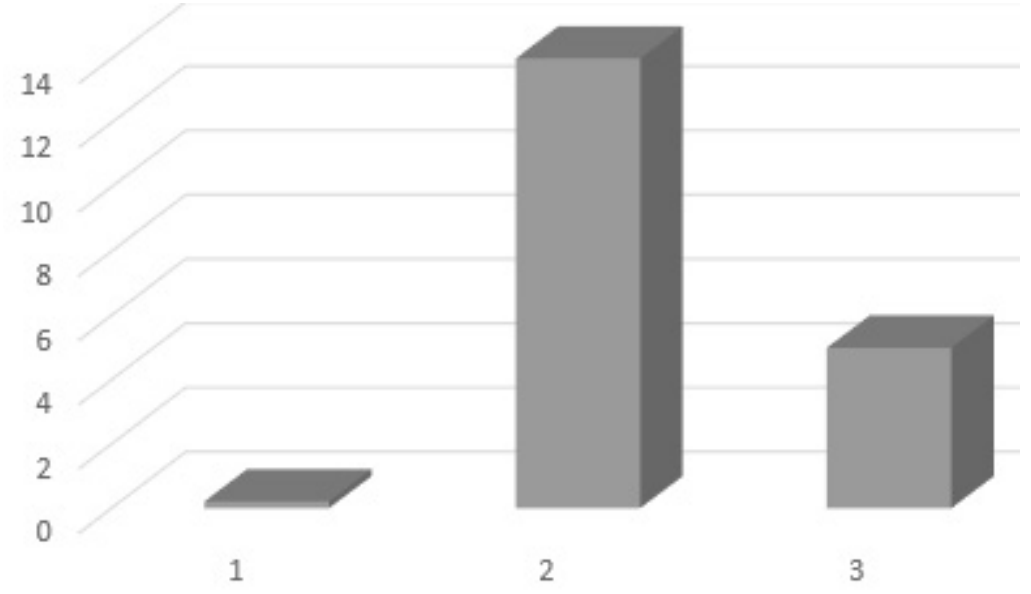

1. Healthy individuals

2. Patients with obliterating arterial disease of the lower extremities a day after surgery

3. Patients with obliterating arterial disease of the lower extremities after 5 sessions of HBO

Figure 2. The effect of hyperbaric oxygenation on oxygen deficiency in patients with chronic obliterating arterial disease of the lower extremities

Anemia was observed in the studied patients as well as a decrease in the oxygen-binding capacity of circulating red blood cells. These pathogenetic factors formed the basis of hemic hypoxia $(7.1+0.4 \%)$. In addition, insufficient oxygen supply to the tissues $(14.5+0.15 \%)$ was also caused by decreased cardiac output, apparently due to a decrease in cardiac muscle function.

Along with a reduced oxygen supply to the tissues $(\mathrm{p}<0.001)$ in the study patients, there is also a greater oxygen consumption by the body $\left(\mathrm{VO}_{2}\right), 22.5 \%$ above normal was noted. This index indicates an imbalance of energy metabolism in the body. The reason is likely stressogenic factors (pain, inflammatory processes, resorption of toxic products of tissue destruction into the circulation, psycho-emotional discomfort due to the surgery and hospitalization, etc.), that trigger a catabolic state.

These results indicate the tension of oxygen homeostasis stabilization systems in these patients, which in case of any complication or accompanying pathology can rapidly result in oxygen debt of tissues with decompensation of organs and systems of the body. 
Along with usual postoperative intensive therapy, inclusion of hyperbaric oxygenation sessions resulted in positive changes in a number of oxygen balance parameters. The function of external respiration was improved, but not reliable; and there was a reduction in pulmonary shunting contributing to the reduction in pulmonary hypoxia from 2.4 to $1.62 \%$.

The oxygen transport function of hemoglobin (HGG) improved significantly $(\mathrm{p}<0.01)$ due to an increased oxygen binding capacity of red blood cells and therefore a greater carrying capacity of oxygen by the blood. The functional capacity of the heart was found to be greater; the cardiac output increased, and the degree of circulating hypoxia was reduced. The integral index of oxygen deficiency decreased almost 2.8 times, and the oxygen supply increased by $84.5 \mathrm{ml} / \mathrm{min}$ in comparison with the initial data.

Consequently, the amount of oxygen that is transported to the organs and systems of the body, after the sessions of HBO is sufficient for metabolic function. In the context of absolutely sufficient oxygen flow and transport to the tissues, we found some decrease in the volume of gas consumption in comparison with the initial data (by $7.9 \mathrm{ml} / \mathrm{min}$ - see table 1); however, it still does not meet that of control individuals.

\section{Discussion}

Disease caused by occlusive lesions of the arteries of the lower extremities is widespread, and follows a steadily progressive course, causing early disability and significant mortality and therefore there is an urgent need to improve treatment methods for patients with this pathology.

In vascular surgery, lower limb ischemia with decompensation of arterial circulation is the most critical complication of arterial disease [4]. In recent years, interest in this problem has not waned. The steadily progressive nature of obliterating arterial disease, means these patients maintain high rates of disability, may require lower limb amputations and suffer significant mortality. In the United States, more than 400 thousand patients with obliterating diseases of the peripheral arteries are hospitalized annually and 69 thousand amputations of the feet and limbs per year are performed [10].

Obliterating diseases of the arteries of the lower extremities are associated with local and general oxygen deficit [10]. The muscle tissues of the legs are sensitive to oxygen starvation and cannot function normally when oxygen is deficient. However, under normal atmospheric pressure, even breathing pure oxygen is not able to eliminate this oxygen deficiency at a tissue and cellular level. The latter is possible only in a hyperbaric chamber with increasing oxygen pressure, as under pressure, gases dissolve better in liquids. Inhalation of pure oxygen under normal conditions increases blood oxygen saturation by $4-5 \%$, but in a hyperbaric chamber, where oxygen dissolves more readily in plasma and interstitial fluid, oxygen concentration in the blood exceeds normal values by 20 times [3]. Moreover, it enters the organs and tissues in large quantities, eliminating oxygen starvation, which helps to restore the function of the diseased organ. Indicators determined in this work form the basis for the description of oxygen metabolism in the body. First of all, these are the values of oxygen delivery and consumption, as well as the value of intrapulmonary blood bypass [1]. Consumption of oxygen $\left(\mathrm{VO}_{2}\right)$ is the amount of oxygen actually used by cells. Under normal conditions, consumption and need for oxygen are equivalent. In critical conditions, the need for $\mathrm{O}_{2}$ (metabolic demand) may exceed its consumption (uptake), which results in tissue hypoxia. At rest, the body consumes $220-250 \mathrm{ml}$ of $\mathrm{O}_{2}$ per minute. Normally, $\mathrm{O}_{2}$ consumption is independent of its delivery until $\mathrm{DO}_{2}$ reaches a certain threshold (critical) value [11].

$\mathrm{O}_{2}$ consumption is determined by the oxidative phosphorylation activity of the tissues and depends on the type and functional activity of the tissue at a given time.

In respiratory physiology, shunting is understood as the moving of deoxygenated mixed venous blood from the right side of the heart to the left without normal oxygen uptake occurring in the lungs. This type of shunt is referred as the "right-to-left" shunt, and leads to a decrease in oxygen content of arterial blood. There are also "left-to-right" shunts, where oxygenated blood in the left side of the heart mixes with deoxygenated blood in the right side of the heart, this does not cause hypoxemia. The reduction of intrapulmonary shunt of blood obtained by us as a result of treatment is a very positive result [4].

Utilization of oxygen by the tissues of the body is equalized, approaching the values found in healthy individuals. Synchronously with positive changes in the oxygen balance, we observed improvement in the general status of patients receiving HBO, with a faster recovery, and reduced hospital stay being observed.

Thus, the obtained results once again confirm the necessity to include hyperbaric oxygenation sessions in the intensive postoperative care program for patients with obliterating arterial disease of the lower extremities, undergoing reconstructive arterial surgery. 


\section{Conclusions}

Inclusion of five 45-minute sessions of 1.5 atm hyperbaric oxygenation in a day in the postoperative intensive care of patients with obliterating arterial disease of the lower extremities, undergoing reconstructive vascular surgery, leads to significant improvements in the oxygen balance of the body. This increases the oxygentransport capacity of the blood, increases the metabolic reserves of organs and systems of the body and aligns the metabolic processes of tissues. This certainly proves the necessity of using hyperbaric oxygenation in the postoperative intensive care of certain patients undergoing vascular reconstructive surgery.

\section{References:}

1. Chantre C, Foucher S, Le Hot H. Hyperbaric oxygen therapy, a little-known discipline. Rev Infirm. 2018; 67(242): 14-15. https://doi.org/10.1016/j.revinf.2018.03.012

2. Smith J. Hyperbaric oxygen therapy: exploring the clinical evidence. Adv Skin Wound Care. $2017 ; 30$ (4): E1. https://doi.org/10.1097/01.ASW.0000514208.07205.ce

3. Niezgoda JA. Hyperbaric oxygen therapy: panorama of perspectives. Adv Skin Wound Care. 2017; $30(4): 150$. https://doi.org/10.1097/01.ASW.0000513929.90305.ad

4. Epel $\mathrm{B}$, Halpern $\mathrm{HJ}$. In vivo $\mathrm{pO}_{2}$ imaging of tumors: oxymetry with very low-frequency electron paramagnetic resonance. Methods Enzymol. 2015; 564: 501-27. https://doi.org/10.1016/bs.mie.2015.08.017

5. Yuan M, Ye J, Zhang X. Development of a portable pulse oxymetry simulator system. Zhongguo Yi Liao Qi Xie Za Zhi. 2019; 43(5): 345-347.

6. Vienne JC, Cimetta C, Dubois M, Duburcq T, Favory R, Dessein AF, at al. A fast method for high resolution oxymetry study of skeletal muscle mitochondrial respiratory chain complexes. Anal Biochem. 2017; 528: 5762. https://doi.org/10.1016/j.ab.2017.04.015

7. Mongodi S, Bouhemad B, Iotti GA, Mojoli F. An ultrasonographic sign of intrapulmonary shunt. Intensive Care Med. 2016; 42(5): 912-913. https://doi.org/10.1007/s00134-015-4169-3

8. Hnativ VV. A method for the study of oxygen balance. Pain, anesthesia, and intensive care. 2015; 1: 22-28 (in Ukrainian).

9. Goigo OV. [Practical use of the STATISTICA package for the analysis of biomedical data]. Kyiv: Kyiv; 2015 (in Ukrainian).

10. Bertolino J, Scafi M, Benyamine A, Aissi K, Boufi M, Schleinitz N, et al. Systemic sclerosis and macrovascular involvement: status of the issue in 2019. J Med Vasc. 2019; 44(6): 400-421. https://doi.org/10.1016/j.jdmv.2019.09.002

11. Marino PL. Marino's the ICU book. Philadelphia, PA: Wolters Kluwer Health; 2013. 